\title{
РОЛЬ ЖІНОК У БЛАГОДІЙНОМУ РУСІ НАДДНІПРЯНСЬКОЇ УКРАЇНИ ДРУГОї ПОЛОВИНИ ХІХ СТОЛІТТЯ
}

\section{Волкова I. O.}

\section{ВСТУП}

В історії людства $\epsilon$ події та періоди, інтерес до яких то згасає, то посилюється залежно від конкретно-історичних ситуацій, за яких досвід, набутий під час цих періодів чи подій, набуває особливої актуальності. Якщо такі ситуації мають характер суспільних зламів, переходів суспільства від одного етапу до іншого, посилюється інтерес до періодів, що також відзначалися гостротою соціальних, економічних, політичних суперечностей.

У наш час, коли в Україні відбувається реформування суспільного життя, коли перехід на рівень сучасної цивілізації відбувається дуже боляче, перед історичною наукою постає завдання не лише озброєння людей позитивним досвідом минулого, а й перестороги їх від згубних помилок.

Необхідність актуалізації проблем історії жіночого руху в Україні випливає з ускладнення завдань нинішнього етапу розвитку нашого суспільства. Оновлення країни та гармонізація суспільних відносин $\epsilon$ взаємозумовленими процесами. На тлі грандіозних трансформацій і політичних подій сучасності ускладнюються традиційні та з'являються нові проблеми, що вимагають пошуку їх розв'язання. Гендерна проблема впевнено входить до сучасної картини світу, вимагає переосмислення засад сучасної цивілізації.

У XXI столітті висуваються принципово нові завдання щодо визначення місця жінки в сучасному світі, без розв'язання яких неможливий подальший прогрес людства. У цьому аспекті актуальним $\epsilon$ вивчення історії України другої половини ХІХ століття.

Зважаючи на те, що у другій половині XIX століття населення земель України входило до складу двох імперій - Російської і АвстроУгорської, які відрізнялися як за рівнем соціально-економічного, політичного, так i культурного розвитку, автор обмежує своє дослідження Наддніпрянською Україною, проте враховує взаємо- 
зв'язок і взаєморозвиток культурних процесів, які відбувалися як у Наддніпрянській Україні, так і в Західній Україні.

Друга половина XIX століття була наповнена соціальними конфліктами. 3 одного боку, перші в Російській імперії ліберальні реформи почали давати відчутні наслідки: піднесення духовної культури, внутрішню консолідацію пригноблених націй, зростання національної свідомості. 3 іншого - контрреформи, які означали перемогу консервативних сил царської бюрократії, безземелля й безправ'я селян, чорносотенний розгул великодержавного національного гноблення.

Становище жінок в економічній, соціальній, правовій і культурній сферах життя суспільства свідчіть, що селянська реформа 1861 року, а також подальші реформи судової, адміністративної систем і системи освіти мали історичний прогресивний вплив у губерніях Наддніпрянської України. Пов'язані 3 реформою зміни соціальної структури населення і демографічна ситуація, подальший розвиток буржуазних відносин як у промисловості, так i в сільському господарстві сприяли залученню жінок у суспільне виробництво, підвищенню їх ролі в економічному житті суспільства і розвитку їхнього освітнього рівня. Проте залучення жінок у виробництво не забезпечило фактичної рівності жінок i чоловіків. Набуваючи економічної самостійності, жінка відчувала дискримінацію в оплаті праці та у виборі професійної діяльності, а також у сфері освіти. Незавершеність процесу формування буржуазного законодавства і значний вплив феодальних норм права і моралі погіршували стан жінок у суспільстві, що й сприяло залученню жінок до демократичного руху за соціальні права.

Відсутність самостійних жіночих організацій в Наддніпрянській Україні пояснюється тим, що історично, ще за часів України-Русі, Великого князівства Литовського, козацької держави, соціальний статус жінки в сім’ї, побуті, майнових справах був досить високим.

Жінки Наддніпрянщини досягли у другій половині XIX століття значних успіхів у самореалізації, професійній діяльності та отримали світове (Х.Д. Алчевська як організатор жіночої освіти й автор навчальних посібників) і загальнонаціональне визнання (С. Русова як теоретик педагогії, Олена Пчілка як видавець і літератор, Леся Українка як поетеса).

Соціально-економічний, політичний i культурний розвиток Наддніпрянської України другої половини XIX століття визначив основні напрями суспільної діяльності жінок. Упровадження реформ 
1860-1870-х років не вирішило соціальні та економічні проблеми суспільства. Посилення реакційно-консервативних тенденцій уполітиці уряду викликало рух демократичної громадськості за соціальні та культурні права. Жінки, які брали активну участь у громадських рухах, захищали своє право бути рівноправними членами суспільства, прагнули полегшити скрутне становище народу.

Відсутність політичних свобод та постійний контроль самодержавної системи за діяльністю своїх підданих визначила перевагу благодійного та культурно-просвітницького спрямування в суспільній діяльності жінок другої половини XIX століття. У Наддніпрянській Україні більше, ніж у російських губерніях була розвинута традиція громадської діяльності. За кожної нагоди українське населення намагалося використати всі можливості громадської праці. Про це свідчить участь жінок у земських, культурно-просвітницьких, доброчинних справах.

Суспільно-політичний і національний рух Наддніпрянської України другої половини XIX століття був могутнім чинником загального прогресу українського суспільства, важливим стимулом зростання національної свідомості, формування громадянського суспільства.

Дослідження діяльності жінок у благодійному русі другої половини XIX століття дозволяе визначити внесок жінок у розвиток соціальної сфери суспільства, прослідкувати залучення жінок до суспільної діяльності та демократичного руху широкої громадськості за соціальні права. Соціально-економічні перетворення другої половини XIX століття вплинули на економічне становище представників різних соціальних груп. 3 одного боку, простежувався процес розорення селянських господарств та зубожіння дворянства, а 3 іншого зміцнення буржуазії в сільському господарстві та промисловості, соціальне розшарування на селі, що призводило до появи маси людей, які потребували суспільної допомоги. Вивчення діяльності жіночих благочинних організацій, а також приватних доброчинних товариств дозволяє визначити той внесок, який вони зробили в розширення соціальної допомоги населенню Наддніпрянської України.

Методична основа дослідження базується на конкретноісторичному методі й системному підході до всебічного критичного аналізу документів і літератури, з урахуванням принципу науковості й норм загальнолюдських цінностей. 


\section{1. Соціально-політичні та правові аспекти роботи \\ благодійних товариств другої половини XIX ст.}

Впровадження селянської реформи 1861 року, здійснення комплексу реформ у соціально-економічній сфері торкнулося й сфери «суспільної зневаги». Необхідність прийняти рішення щодо реформування цієї важливої сфери суспільного життя була викликана соціальними змінами, які відбулися внаслідок здійснення цих реформ.

Соціальна допомога населенню надавалась різними благодійними організаціями, як урядовими, так і приватними, та мала становий характер. Створення приватних благодійних організацій до реформи 1861 року було вкрай складним через вороже ставлення царизму щодо розвитку суспільної ініціативи. У березні 1848 року Микола I, злякавшись наслідків революційного руху в країнах Західної Свропи, фактично наклав заборону на створення нових приватних благодійних організацій. Але й до 1848 року процес створення благодійних товариств на підставі особистої ініціативи громадян був ускладнений необхідністю отримання дозволу через Комітет міністрів. Кримська війна сприяла розвитку благодійного руху. Уряд був змушений піти на поступки та підтримати суспільну ініціативу, необхідну самому урядові у військовий час. Так було створено общини «Жалостливых вдов», «Сестер милосердия», які знаходилися під заступництвом імператорської родини.

Аналіз політики уряду щодо приватних благодійних організацій свідчить, що пом'якшення умов створення та діяльності добродійних організацій не було продуманою політичною лінією з боку уряду, а було викликане суспільним рухом та розвитком суспільної ініціативи.

У 1859 році Олександр II був змушений задовольнити клопотання про створення різних благодійних організацій, які надійшли до Міністерства внутрішніх справ, це означало відміну заборони 1848 року на діяльність приватних доброчинних товариств ${ }^{1}$. 31862 року здійснювалась нова політика щодо благодійних товариств, суть якої полягала в офіційному визнанні приватних благодійних організацій та створенні сприятливих умов для їхньої діяльності. Була відмінена необхідність отримання найвищого дозволу після розгляду Комітетом міністрів клопотання про створення благодійного товариства та його статуту. Право затвердження статутів благодійних

1 Линдденмайер А. Добровольные благотворительные общества в эпоху великих реформ. Великие реформы в России 1856-1874 : сборник / ред. Л.Г. Захарова и др. Москва : Изд-во МГУ, 1992. С. 288. 
організацій надавалося Міністру внутрішніх справ у погодженні 3 різними установами. Це значно спрощувало процедуру офіційної реєстрації нових організацій. Тільки за період 3 1861-1863 рр. до Міністерства внутрішніх справ надійшло 43 прохання про затвердження статуту товариств взаємодопомоги, що було значно більше, ніж за весь період правління Миколи $\mathrm{I}^{2}$. Ліберальна політика уряду щодо приватних благодійних організацій пояснюється тим, що діяльність цих товариств полегшувала тягар державних видатків у такій галузі, як допомога незаможнім та жебракам. Проте благодійні товариства, у статуті яких Міністр внутрішніх справ убачав політичні або соціальні завдання, передавались до розгляду Комітетом міністрів або суворо заборонялись самим Міністерством внутрішніх справ. Свідченням цього може слугувати заборона міністерством створення благодійних товариств у Кам'янці та Житомирі ${ }^{3}$. Спеціальними законодавчими актами категорично заборонялась діяльність товариств, які не отримали на свою роботу урядового дозволу. Вважалося незаконним будь-яке легально діюче товариство, діяльність якого відхилялась від статуту, схваленого Міністерством внутрішніх справ.

Вивчаючи систему «суспільної зневаги», ми бачимо іï дійову неспроможність у соціально-економічних умовах другої половини XIX століття, оскільки ії підгрунтям була станова допомога. Надання соціальної допомоги потребуючим представникам селянського стану здійснювалося на підставі статей 580, 581, 582 Статуту суспільної зневаги, згідно з яким «старі, немічні та калічні члени сільських товариств, якщо вони не мають родичів або якщо незаможні <..>, утримуються за рахунок селянських товариств» ${ }^{4}$. Обов'язок 3 надання допомоги неімущим та сиротам селянського стану закріплявся у статті 179, IX том «Зведення законів Російської імперії»: «Загальне положення про селян, що вийшли з кріпосної залежності». Нестача за цією системою соціальної допомоги найбіднішому населенню, а також iii невідповідність потребам суспільства була пов'язана з розоренням селянських господарств та зубожінням селянства після впровадження реформи 1861 року. Відсутність у селянських товариств фінансової

${ }^{2}$ Извлечение из отчета министра внутренних дел за 1861,1862 и 1863 гг. Санкт-Петербург, 1865. С. 135.

3 Євселевський Л.І. Фарина С.Я. Просвіта в Наддніпрянській Україні: історичний нарис. Київ : Всеукр. т-во «Просвіта» імені Тараса Шевченка, 1993. C. 24.

4 Максимов Е.Д. Сословное призрение в России. Вестник благотворительности. Санкт-Петербург, 1898. № 4. С. 30. 
можливості надати необхідну соціальну допомогу, чимала кількість селян, що потребували «суспільного призору», відсутність у селян організованих форм благодійності та поширення в селянському середовищі добровільної допомоги у вигляді милостині - все це робило станову форму допомоги селянам невідповідною соціальним потребам. Становий характер соціальної допомоги, яка надавалась представникам міщанської та ремісницької верств, закріплявся статтею 200 Статуту Суспільного призору. Згідно зі ст. 571, II том, частина I «Зведення законів Російської імперії», а також статтями 521, 535-550, том IX «Зведення законів Російської імперії», утримання представників цих станів, а також оплата наданої їм медичної допомоги в лікарнях здійснювались за рахунок цих станів ${ }^{5}$.

Міське Положення від 16 червня 1870 року, що визначало всі основні видатки міст, не включало в обов'язкові міські видатки плату за лікування незаможних членів суспільства в лікарнях наказів або земств ${ }^{6}$. Унаслідок визначених юридичних положень селянські, міщанські та ремісницькі товариства були повинні виконувати «обов'язок із суспільного призору» представників своїх станів, тоді як обов'язки заможних верств суспільства у зазначених правових документах не визначалися. Це фактично призводило до того, що обов'язок надання соціальної допомоги був поширений тільки на економічно неспроможні верстви суспільства.

Необхідність реформування системи «суспільного призору», надання дієвої допомоги неімущому населенню, вимагало реформи існуючої системи соціальної допомоги. До 1868 року урядова діяльність із суспільного призору здійснювалася через спеціально створені установи. 1 липня 1868 року було затверджено рішення Державної Ради, за яким з 1869 року діяльність у цій сфері переходила до земського управління, а капітали наказів суспільного призору, так звані капітали 1-го розряду, розміщені в облігаціях Головного товариства російської залізниці, мали розподілятися між земськими установами тих губерній, в яких власних коштів благодійних установ було недостатньо для їх утримання. За законом від 1 липня 1868 року, в розпорядження земств на благодійні цілі переходили всі прибутки

5 Максимов Е.Д. Сословное призрение в России. Вестник благотворительности. Санкт-Петербург, 1898. № 4. С. 34.

${ }^{6}$ Городовое положение от 16 июня 1870 г. Сборник распоряжений $u$ постановлений по общественному управлению в городах с введением в них нового городового положения. Санкт-Петербург, 1878-1879. Т. 1; приложение. 
наказів, що отримувалися 3 різних економічних підприємств. Безпосередньо до земств переходили капітали 2-го розряду, які використовувались на повсякденні потреби благодійної діяльності ${ }^{7}$.

Капітал 1-го розряду розподілявся між губерніями на основі даних, одержаних Міністерством внутрішніх справ від наказів та управ суспільного призору, про видатки та прибутки цих відомств за період 3 1861-1865 pр. За ними була визначена середня цифра по прибутках та видатках, причому якщо останні перевищували перші, то різниця між ними капіталізувалася з 4,5\%, і за отриманою сумою визначався той капітал, який підлягав передачі земству на покриття видатків з надання допомоги найбіднішому населенню. Система розподілу капіталів між губерніями поставила земства у найтяжчі умови та фактично ускладнила розвиток системи соціальної допомоги в губерніях. Так, Полтавське губернське земство отримало з капіталу свого наказу, що становив 410000 руб., тільки 30000 руб., а після тривалих клопотань ще 185 000. Катеринославському губернському земству не було додано 235000 руб., і тільки Херсонське земство отримало від Міністерства внутрішніх справ суму більшу за ту, що залишив наказ. Але цей випадок був поодиноким ${ }^{8}$.

Урядова політика щодо системи суспільного призору поклала всю відповідальність за діяльність у цій сфері на земства. Уряд фактично усунувся від надання допомоги найбіднішому населенню. Робота земств 3 надання соціальної допомоги населенню ускладнювалася постійними фінансовими нестачами та терміновими справами. Але, незважаючи на складні умови діяльності, земства мали значний вплив на розвиток суспільної ініціативи та залучали широку громадськість до участі у створенні благодійних товариств. Вилучивши зі сфери суспільного призору медичну допомогу як самостійну частину управління та взявши майже всі видатки щодо іiї організації на власний рахунок, земства тим самим звільнили міські, станові та приватні товариства від необхідності дбати про медичну допомогу та надали їм більш широкі можливості у справах розвитку благодійності, що сприяло розвитку суспільної ініціативи зі створення різних благодійних товариств.

На активізацію благодійного руху в губерніях Наддніпрянської України великий вплив мало прагнення громадськості до надання

7 Максимов Е.Д. Сословное призрение в России. Вестник благотворительности. Санкт-Петербург, 1898. № 4. С. 78.

${ }^{8}$ Там же. С. 78. 
культурної та матеріальної допомоги населенню. Ця система моральних цінностей була визначною для жіночої психології та в соціальній діяльності жінок. Прагнення надати допомогу ближньому, полегшити страждання хворих та калічених, допомогти людям, які бажають отримати освіту, - це невід'ємна частина моральних основ жіночої психології. У зв'язку з цим благодійна сфера діяльності була особливо важливою для жінок, оскільки сприяла реалізації їхніх природніх психологічних якостей.

Жінки брали участь у роботі різних доброчинних товариств, але сфера їхньої діяльності була обмежена політикою самодержавства, яка забороняла політичні та соціальні організації, контролювала суспільну діяльність своїх підданих. Жінки й чоловіки були рівні у своєму політичному безправ'і, що визначило несприйняття жінками Наддніпрянської України ідей західноєвропейського радикального фемінізму. Жіночі організації, метою яких було досягнення політичної та соціальної рівності, були характерні для країн, в яких існувала правова система, але разом із тим права жінок не були захищені законом. Оскільки політичні права жінок Російської імперії проти прав жінок Західної Європи були значно обмежені політичною системою самодержавства, то саме це й визначило своєрідність суспільної діяльності жінок, їхню участь у доброчинних товариствах.

Ліберальна політика уряду стосовно приватних благодійних організацій у сполученні 3 «духом доброчинності», характерним для цього періоду, сприяли виникненню нових благодійних організацій у період з 1855 до 1880 року. За даними Міністерства внутрішніх справ, у 1855 році було лише 40 приватних доброчинних товариств i 73 приватних благодійних закладів. У 1880 році було вже 348 приватних благодійних товариств і 225 приватних благодійних закладів. Ці підрахунки є неповними через відсутність вичерпної інформації, оскільки деякі благодійні товариства відмовилися надавати дані під час збору статистичних відомостей9

Дослідження роботи жіночих благодійних організацій та участі жінок у діяльності різних благодійних товариств грунтується на вивченні архівних матеріалів та звітів благодійних товариств Наддніпрянської України, на аналізі даних губернських пам'ятних та довідкових видань, опублікованих губернськими статистичними комітетами. Дослідження характеру жіночого благодійного руху

9 Императорское человеколюбивое общество: Сборник сведений по общественной благотворительности : в 7 т. Санкт-Петербург, 1875-1886. 
виявляс основні напрями, за якими він здійснювався. Жіночі добровільні товариства мали професійний та доброчинний характер, метою була просвітницька, кооперативна діяльність. Вони були як помірними, так і радикальними. Ці товариства об'єднувало прагнення жінок до самостійної суспільної діяльності, самореалізації, до створення незалежних суспільних організацій.

\section{2. Жіночій благодійний рух: характеристика основних напрямів}

Аналіз діяльності жіночих благодійних організацій свідчить, що ці товариства об'єднували представниць різних соціальних верств. Створені представницями заможних верств суспільства жіночі товариства залучали до своєї діяльності купчих, міщанок, різночинок. Деякі 3 цих товариств мали на меті надання допомоги всім неімущим, незважаючи на станову належність і віросповідання. Це було значним кроком уперед у наданні соціальної допомоги, оскільки більшість благодійних товариств мали становий або релігійний характер. Важливо зазначити, що реформа системи урядового призору не вирішила проблему соціальної допомоги населенню, а здебільшого поставила суспільство перед необхідністю самостійно шукати шляхи іiі вирішення. За таких умов діяльність жіночих благодійних організацій та участь жінок у благодійному русі мали значний вплив на пошук суспільством шляхів розв'язання проблеми соціальної допомоги матеріально незабезпеченим верствам населення.

До доброчинних організацій, які виникли за приватною ініціативою, належали такі товариства Наддніпрянської України: «Одеське жіноче благодійне товариство», «Дамське товариство допомоги незаможним породіллям міста Одеси», «Катеринославське благодійне товариство», «Катеринославське товариство піклування про дітей», «Харківське товариство призору малолітніх сиріт», «Полтавське дамське благодійне товариство», Київське, Чернігівське та Житомирське благодійні товариства.

Аналіз статутів благодійних організацій визначеного спрямування свідчить, що вони, по-перше, мали безстановий характер, по-друге, надавали допомогу найбіднішому населенню незалежно від віросповідання. Доброчинні товариства створювались представницями заможних верств суспільства, які вважали свою діяльність суспільним обов'язком. Більшість членів правління виконували свої обов'язки 
безкоштовно, вважаючи, що «поліпшення побуту народу є одним із найголовніших завдань цього століття» ${ }^{10}$.

Одним із перших серед приватних благодійних організацій було створено «Одеське жіноче благодійне товариство», засноване у 1829 році за активної участі княгині Є.К. Воронцової та графині Р.С. Єдлінг. Метою товариства була «допомога бідним незалежно від їхнього віросповідання, статі, віку та звання» ${ }^{11}$. Однією 3 основних сфер діяльності «Одеського жіночого благодійного товариства» була робота 3 надання притулку та 3 виховання дітей-сиріт. Кошти товариства складались як із щорічних внесків членів та добровільних пожертвувань, так і з прибутків крамниць, які належали товариству. Важливість діяльності цього товариства у вирішенні соціальних проблем міста визначилася вже у 1833 році, коли через неврожай маса голодних людей потребувала допомоги. «Одеське жіноче благодійне товариство» утримувало протягом зими 1833 року 5 тисяч незаможних. 1 березня 1834 року було відкрито Будинок сиріт, в якому виховувалося 70 дітей, було створено відділення для немовлят, де діти утримувались до семирічного віку ${ }^{12}$. У 1854 році «Одеське жіноче благодійне товариство» відкрило притулок для жінок похилого віку та жінок-інвалідів. На кошти княгині С.К. Воронцової, яка пожертвувала фонду 110 рублів, у 1859 році було відкрито Михайло-Семенівський сирітський дім «для призору сиріт чоловічої статі з народним при ньому училищем, а також церкву» ${ }^{13}$. У військові роки (1854-1856) «Одеське жіноче благодійне товариство» надавало допомогу населенню, постраждалому від військових дій. Було створено «Комітет піклування про бідних», який тільки протягом зими 1856-1857 pp. відкрив безкоштовну їдальню для бідних та надав матеріальну допомогу 1217 християнським і 260 єврейським родинам ${ }^{14}$.

10 Значение частной благотворительности для общества. Журнал землевладельиеев. Москва, 1859. Т. 6, № 21. С. 69.

11 Шведов А. Краткая историческая записка о развитии женского благотворительного общества со времени его основания до 1885 г. Одесса, 1885. С. $2-3$.

12 Державний архів Одеської області. Одеса. Ф. 2. ОП. 1. Д. 836. Л. 11.

13 Державний архів Одеської області м. Одеса. Ф. 2. ОП. 1. Д. 836. Л. 9.

${ }^{14}$ Извлечение из отчета Женского благотворительного общества в Одессе за 1856 год. Журнал Министерства внутренних дел. Санкт-Петербург, 1857. Ч. 26. Кн. 9. Отд. 5. С. 2-7. 
Киянам значну допомогу надавало «Товариство допомоги бідним міста Києва», яке було засновано у 1834 році $^{15}$. Його головна мета полягала в тому «чтобы низшему, стыдящемуся просить милостыню и ютящемуся на чердаках и подвалах населению, оказать помощь не только деньгами и предметами первой необходимости, но и приисканием необходимой работы» ${ }^{16}$. Переважна більшість посад, як виконавчих, так і адміністративних, у цьому товаристві належала жінкам. У 1851 році товариство утримувало на власні кошти бідних дівчат у пансіоні графині Левашової. 31853 року товариство проводить благодійні бали, вистави 3 метою збирання коштів на благодійну діяльність, отримуючи від їх проведення до 5000 рублів на $\mathrm{pi \kappa}^{17}$. Це дозволило товариству надати значну допомогу населенню Києва в боротьбі з холерою.

Товариство допомагало жінкам знайти роботу та житло. На кошти товариства було відкрито контору, яка приймала замовлення на швейні вироби, і в якій дівчата з бідних родин навчалися ремеслу. У 1859 році за заповітом вдови генерала Ловцова, за першим шлюбом Суліми, товариство отримало будинок і сад для облаштування притулку для 12 престарілих чоловіків та жінок. У 1859 році товариством було засновано дешеві квартири, кімнати 3 повним безкоштовним утриманням для 12 «ветеранів обох статей», 12 сестер милосердя, а також для жінок, які потребували прихистку ${ }^{18}$.

Збільшення звернень до Київського благодійного товариства призвело до необхідності розділити місто на сім дільниць: Палацову, Печерську, Старокиївську, Либідську, Подільську, Плоску та Куренівську, які очолювали піклувальниці, що відповідали за надання допомоги бідним. У цих районах товариство організувало безоплатну медичну допомогу, найбіднішому населенню видавалися безкоштовні ліки. 31865 року активна учасниця «Товариства допомоги бідним міста Києва», дружина генерал-губернатора Л.І. Безак, влаштувала школу рукоділля для дівчат із незаможних родин, яку в 1865 році

15 Киевское благотворительное общество. Памятная книжка Киевской губернии. Киев, 1899. С. 420.

16 Киевское благотворительное общество. Памятная книжка Киевской губернии. Киев, 1899. С. 420.

17 Киевское благотворительное общество. Памятная книжка Киевской губернии. Киев, 1899. С. 421.

18 Киевское благотворительное общество. Памятная книжка Киевской губернии. Киев, 1899. С. 7. 
відвідували 20 дівчат, а у 1867 році - $100^{19}$. У 1872 році товариство відкрило «Сулімовську дешеву їдальню», яка за перший рік роботи забезпечила обідами 50000 чоловік, і крамницю для «забезпечення збуту виробів бідним жінкам, а також для найлегшого отримання роботи» ${ }^{20}$. Товариство сприяло розвитку освіти, заснувало ремісницьку школу для хлопців та влаштувало безкоштовне проживання і харчування для 10 дівчат із бідних родин, які навчалися у Фундуклєївській гімназії.

Аналіз діяльності доброчинних організацій свідчить, що поєднання благодійної, просвітницької діяльності 3 наданням безпосередньої допомоги в отриманні роботи стало значним внеском у розвиток соціальної сфери суспільства. Так, вивчення звітів правління «Дамського товариства допомоги незаможним породіллям міста Одеси» 31883 до 1893 року дає підстави зробити висновок про значну соціальну допомогу, що була надана населенню. Якщо у 1883 році до товариства звернулися 295 жінок, то у 1893 році матеріальну і медичну допомогу отримали 1215 жінок $^{21}$.

Поєднання в діяльності доброчинних жіночих організацій різних заходів - безпосередньо благодійних (організація притулків для людей похилого віку та дітей-сиріт, відкриття дешевих їдалень і квартир, допомога у боротьбі з голодом та інфекційними захворюваннями) 3 просвітницькими (відкриття шкіл рукоділля, ремісницьких майстерень, надання стипендій та утримання учнів 3 незаможних родин) та трудовими (відкриття крамниць, де реалізовувалась продукція, пунктів пошуку роботи) - дозволило жінкам найбільш повно враховувати потреби населення у наданні соціальної підтримки. Жінки на практиці створили нову систему суспільної допомоги, яка засновувалась не на патріархальній системі «державного призору», вона враховувала реальні потреби населення, дозволяла знайти найбільш ефективні способи вирішення соціальних проблем.

Держава не надавала допомоги приватним благодійним товариствам, проте здійснювала постійний контроль за їхньою діяльністю. Звіти роботи благодійних товариств через генерал-

19 Киевское благотворительное общество. Памятная книжка Киевской губернии. Киев, 1899. С. 8.

${ }^{20}$ Общество для помощи бедным г. Киева. Календарь Юго-Западного края на 1873 год / ред. В. Борисов, П. Чубинский. Киев : изд. В. Борисова и П. Чубинского, 1873. С. 322.

21 Отчет правления Дамского общества вспомоществования бедным роженицам г. Одессы за 1883 г. Одесса, 1884. С. 4. 1893. С. 3. 
губернатора щорічно надавалися до Міністерства внутрішніх справ, яке контролювало дотримання статуту та організаційну діяльність товариств. Разом із тим застарілі статті законодавства щодо реєстрації благодійних товариств створювали бюрократичні перепони їхній діяльності. Так, статті 174, 175 Статуту суспільного призору значно ускладнювали процедуру затвердження благодійних товариств, а закон 1817 року про повне забезпечення при відкритті благодійних закладів фактично обмежував можливість їх створення на основі приватної ініціативи $^{22}$. Жінки, незважаючи на бюрократичні перепони, домагалися відкриття благодійних організацій різних спрямувань, збираючи кошти шляхом проведення культурних заходів та самовіддано виконуючи важку роботу з надання соціальної допомоги населенню.

Представниці заможних верств суспільства робили цільові пожертвування на різні суспільні потреби, що разом із діяльністю доброчинних організацій було значним внеском у розвиток соціальної сфери суспільства. Так, П.Г. Терещенко пожертвувала в капітал Київського благодійного товариства 30 тисяч рублів на утримання 10 чоловік та 2 тисячі рублів на медичні цілі для безкоштовної лікарні, яку відкрила у 1891 році графиня С.С. Ігнатьєва ${ }^{23}$. Усі безкоштовні лікувальні заклади Покровського монастиря було створено коштом княгині Олександри Петрівни ${ }^{24}$. Графиня М.В. Браницька фінансувала відкриття дитячого притулку в м. Білій Церкві 3 матеріальним забезпеченням 30 дітей і передала для нього власну ділянку землі й сад $^{25}$. Землевласниця О.Н. Нірод пожертвувала ділянку землі на березі річки для заснування санаторію для хворих дітей. Дружина Волинського губернатора Є.С. Трєпова відкрила дитячій санаторій у Житомирі та в сосновому лісі у Будаєвці ${ }^{26}$.

Доброчинною за своїм характером була діяльність жінок у різних клерикальних організаціях, які діяли в межах православної церкви.

22 Максимов Е.Д. Законодательные вопросы общественного попечения о бедных. Вестник благотворительности. Санкт-Петербург, 1897. № 12. С. 21-22.

23 Максимов Е.Д. Законодательные вопросы общественного попечения о бедных. Вестник благотворительности. Санкт-Петербург, 1897. № 10. С. 101.

24 Максимов Е.Д. Законодательные вопросы общественного попечения о бедных. Вестник благотворительности. Санкт-Петербург, 1890. № 5-6. С. 115.

25 Максимов Е.Д. Законодательные вопросы общественного попечения о бедных. Вестник благотворительности. Санкт-Петербург, 1890. № 2. С. 100.

26 Максимов Е.Д. Законодательные вопросы общественного попечения о бедных. Вестник благотворительности. Санкт-Петербург, 1898. № 8. С. 113. 
«Крестовоздвиженская община сердобольных сестер» та «Орден сердобольных вдов», засновані в період Кримської війни, мали відділення в губерніях Наддніпрянської України.

Допомога незаможним верствам населення на основі християнської благодійності була метою таких організацій, як «Одесская Стурдзовская богадельня сердобольных сестер», «Община сестер милосердия г. Екатеринослава», «Старобельская община Всех скорбящих радости», «Черниговская община сестер милосердия святого Феодосия Углицкого».

Аналіз діяльності цих організацій свідчить про іiі обмеження медичною допомогою, уходом за хворими, інвалідами й дітьмисиротами. Клерикальні благодійні організації переважно надавали допомогу православному населенню, що обмежувало сферу їхньої діяльності. Разом із тим під час військових дій, неврожаю або розповсюдження інфекційних захворювань діяльність клерикальних благодійних організацій допомагала у вирішенні соціальних проблем суспільства. Прикладом $є$ активна допомога сестер «Струдзовской богадельни» та ігумені цієї общини Є.А. Хитрово пораненим солдатам i населенню, постраждалому під час Кримської війни, яка неодноразово відзначалась Н.I. Пироговим як найважливіша діяльність на користь Батьківщині ${ }^{27}$.

Скасування кріпацтва і подальший розвиток буржуазних відносин вимагали підвищення освітнього рівня населення Наддніпрянської України. Недостатня кількість початкових шкіл та спеціалізованих навчальних закладів, навчання російською мовою ускладнювали процес для корінного населення, яке проживало в сільській місцевості. В умовах насильницької русифікації, культурної дискримінації просвітницька діяльність була одним із найважливіших напрямів суспільного руху.

До благодійних організацій просвітницького спрямування належать такі товариства: «Общество попечительства о женском образовании в городе Екатеринославе», «Николаевское общество вспомоществования недостаточным лицам, стремящимся к образованию», «Общество распространения женского образования в г. Одессе», «Харьковское общество распространения грамотности в народе». Ці доброчинні організації сприяли підвищенню освітнього і культурного рівня

${ }^{27}$ Пирогов Н.И. Военно-врачебное дело и частная помощь на театре войны в Болгарии и в тылу действующей армии в 1877-78 гг. Санкт-Петербург, 1879. C. 339-340. 
населення Наддніпрянської України. В роботі благодійних організацій просвітницького спрямування брали участь як жінки, так і чоловіки.

Якщо діяльність «Николаевского общества вспомоществования недостаточным лицам, стремящимся к образованию» та «Общества распространения женского образования в г. Одессе» зосереджувалась на наданні матеріальної допомоги учням міських навчальних закладів i університетів та зборі коштів, то діяльність «Общества попечительства о женском образовании в г. Екатеринославе» полягала не тільки у виданні посібників, але й включала створення безкоштовної жіночої школи з класами рукоділля та проведення народних читань ${ }^{28}$.

Просвітницьку роботу здійснювало «Харьковское общество распространения грамотности в народе», статут якого було затверджено 24 березня 1869 року. Почесними членами товариства були Х.Д. Алчевська, Ф.П. Максимович, М.Д. Раєвська ${ }^{29}$. Товариство мало 5 повітових відділень та 10 філій у Харкові. Просвітницька робота товариства зосереджувалась у трьох напрямах: відкриття загальноосвітніх, ремісницьких та недільних шкіл, організація народних читань та видання книжок. Товариство відкрило 123 сільські бібліотеки-читальні, створило 7 аудиторій для народних читань у Харкові та 6 аудиторій у повітових відділеннях. Було відкрито літню колонію для хворих дітей, 3 міські та 1 сільську школи, 1 чоловічу та 2 жіночі ремісницькі школи, створені недільні школи для чоловіків і жінок ${ }^{30}$.

Аналіз діяльності жінок у благодійних організаціях просвітницького спрямування показує їхню активну участь у створенні цих організацій та їхню самовіддану просвітницьку роботу. Відсутність станового і релігійного поділу під час надання допомоги населенню благодійними просвітницькими товариствами свідчить про їхній демократичний характер. Жіночий рух за право отримання освіти та вільний вибір професії знайшов відображення в діяльності жінок у культурно-просвітницьких організаціях, де жінки на практиці могли реалізувати прагнення до створення жіночих загальноосвітніх та спеціальних навчальних закладів. Спільна робота жінок і чоловіків пояснювалось також тим, що учасниці суспільного руху

28 Отчет о деятельности общества попечительства о женском образовании в г. Екатеринославле за 1891-92 гг. Екатеринославль, 1893. С. 29.

${ }^{29}$ Отчет о деятельности Харьковского общества распространения в народе грамотности за 1898 г. Харьков, 1899. С. 355.

${ }^{30}$ Отчет о деятельности Харьковского общества распространения в народе грамотности за 1898 г. Харьков, 1899. С. 360-370. 
Наддніпрянської України не протиставляли себе чоловікам, розуміючи своє завдання як «питання про співпрацю жінок з чоловіками у справі розвитку культури» ${ }^{31}$.

Розвиток промисловості залучає жінку до виробничої діяльності. Успіхом жіночого руху за вільний вибір сфери стають «інтелігентні професії»: виховательки, перекладачки, вчительки, палітурниці, фельдшериці, акушерки. Значна кількість жінок працює у швейних та оправних майстернях, пральнях тощо.

Соціальна незахищеність жінок у випадку хвороби або звільнення змушує ї створювати професійні благодійні організації - професійні спілки на основі взаємодопомоги. До таких організацій належали: «Киевское общество взаимопомощи повивальных бабок и фельдшериц», «Общество вспомоществования гувернанткам, учительницам и воспитательницам г. Одессы», «Взаимовспомагательное общество фельдшеров и фельдшериц г. Егатеринослава», «Общество взаимного вспомоществования акушерок г. Одессы».

Аналіз роботи цих товариств свідчить про поєднання діяльності, яка була спрямована на підвищення професійного рівня членів, з їх матеріальною підтримкою та пошуком роботи. У професійних благодійних товариствах жінки працювали разом із чоловіками.

Вивчення звітів товариств взаємодопомоги показує, що їхні члени усвідомлювали, що тільки активна робота з покращення соціального становища членів різних професійних товариств може змінити їхнє важке економічне становище. Наприклад, діяльність «Общества взаимного вспомоществования акушерок г. Одессы» включала такі напрями: просвітницький - організація наукових читань і створення бібліотеки; професійний - надання роботи акушеркам (товариство відкрило спеціальні денні та нічні чергові акушерські пункти); безпосередньо благодійний - створення притулку для старих, самотніх жінок, які працювали акушерками, матеріальна підтримка членів товариства $^{32}$.

Професійні жіночі благодійні організації надавали допомогу жінкам усіх соціальних верств, національностей і віросповідань, допомагали у вирішенні їхніх соціальних проблем, що в умовах відсутності

${ }^{31}$ Женская газета. 1912. № 9. С. 2.

32 Отчет взаимного вспомоществования общества акушерок г. Одессы за 1891 г. Одесса, 1892. С. 3-5. 
трудового законодавства Російській імперії мало важливе значення для захисту професійних інтересів жінок.

\section{ВИСНОВКИ}

Робота жінок у благодійних товариствах різних напрямків показує, що ці товариства мали значний вплив на створення нової системи соціальної допомоги, яка формувалася у пореформений період. Активність жінок $з$ організації приватних благодійних товариств доброчинних, клерикальних, професійних, просвітницьких - була викликана їх прагненням до суспільної діяльності, створення незалежних суспільних організацій. Обмеження сфери зайнятості жінок роботою у благодійних товариствах було пов'язане як з політичною системою, яка забороняла діяльність політичних організацій, так і з особливостями жіночої психології, що відбилося у прагненні надати допомогу незаможнім верствам населення. Робота жінок у благодійних товариствах була частиною благодійного руху широкої громадськості, засновувалась на співпраці жінок і чоловіків у створенні нової системи соціальної допомоги.

Вивчення діяльності жіночих доброчинних товариств другої половини XIX століття виявило таке: благодійність розглядалася як вельми престижна форма громадської діяльності та була почесним обов'язком для заможних членів суспільства; в роботі жіночих доброчинних товариств важливими характеристиками були цілеспрямованість і наполегливість у подоланні перешкод, а також регламентування як діяльності самого товариства, так і функціонування закладів, які йому належали.

Таким чином, вивчення ролі жінок у благодійному русі другої половини XIX століття дозволяє зробити висновок про значний внесок жінок у розвиток соціальної та культурно-освітньої сфер пореформеного суспільства Наддніпрянської України. Активна участь жінок у благодійному i просвітницькому русі була пов'язана із соціально-економічними трансформаціями, які відбулися в результаті реформ 60-70-х років ХІХ століття, розвитком національної свідомості, громадянського суспільства, суспільного руху за соціальні права. Діяльність жінок здійснювалась у межах різних суспільних рухів від ліберального до революційно-демократичного, але в основі їхньої роботи було прагнення до самостійної суспільної діяльності та визначення власного суспільного статусу в нових соціальноекономічних умовах трансформації суспільства. Робота жінок зі створення благодійних товариств різних спрямувань була соціально 
необхідною сферою діяльності. Жіночий благодійний рух виробив форму соціальної допомоги, яка найбільш повно відповідала потребам сучасного суспільства. Відсутність станового і релігійного поділу під час надання допомоги населенню, поєднання в діяльності жіночих благодійних товариств доброчинної та професійної допомоги з допомогою соціальної адаптації було визначними рисами жіночого благодійного руху, на відміну від діяльності офіційних і клерикальностанових благодійних товариств. Сполучення благодійної діяльності жінок 3 культурно-просвітницькою роботою допомагало жінкам щонайповніше враховувати матеріальні та культурні потреби найбіднішого населення і випрацьовувати основні заходи з поліпшення умов життя найбільш бідних верств населення.

Діяльність жінок у національно-культурному русі, спрямована на відродження української культури і підвищення освітнього рівня населення, стала основою створення жіночих організацій, які метою своєї діяльності вважали сполучення культурно-освітньої та політичної роботи. Внесок жінок у відродження української культури, їхня самовіддана робота земськими вчительками, виховательками, медичними працівниками, а також їхня літературно-видавницька діяльність сприяли підвищенню національної самосвідомості українського народу, розвитку культурно-освітнього рівня населення. Суспільна діяльність жінок досліджуваного періоду прогресивно вплинула на розвиток соціально-культурної сфери пореформеного суспільства і була значним кроком в емансипаційному русі жіноцтва.

\section{АНОТАЦІЯ}

Статтю присвячено дослідженню суспільної діяльності жінок Наддніпрянської України другої половини XIX століття. Розглянуто участь жінок у створенні та діяльності благодійних товариств різних напрямів. Проаналізовано внесок жіноцтва у розвиток соціальної сфери пореформеного суспільства. Обгрунтовано висновок, що жіночий благодійний рух виробив форму соціальної допомоги населенню, яка найбільш повно відповідала потребам тогочасного суспільства. У діяльності жіночих благодійних товариств визначено такі характерні риси: відсутність станового та релігійного поділу під час надання допомоги населенню, поєднання в їхній діяльності доброчинної, професійної допомоги 3 допомогою із соціальної адаптації. Доведено, що це відрізняло жіночий благодійний рух від діяльності офіційних та клерикально-станових благодійних товариств. Визначено, що сполучення благодійної діяльності жінок з культурно- 
просвітницькою роботою допомагало жінкам найбільш повно враховувати матеріальні і культурні потреби найбіднішого населення та випрацьовувати основні заходи допомоги потребуючим верствам населення.

\section{ЛІТЕРАТУРА}

1. Державний архів Одеської області. Одеса. Ф. 2. ОП. 1. Д. 836.

2. Євселевський Л.І. Фарина С.Я. Просвіта в Наддніпрянській Україні: історичний нарис. Київ : Всеукр. т-во «Просвіта» імені Тараса Шевченка, 1993. 127 с.

3. Женская газета. Одесса, 1912. № 9.

4. Журнал землевладельцев. Москва, 1859. Т. 6. № 21. 174 с.

5. Законы гражданские : Свод Законов изд. 1900 г.: со включением позднейших узаконений и разъяснений по решению общего собрания $и$ Гражданского кас. Департамента Правительственного Сената с 1866 по июль 1990 гг. / под. ред. А.Г. Гаугера. Санкт-Петербург, 1902. Т. 10. Ч. $1.868 \mathrm{c.}$

6. Извлечение из отчета министра внутренних дел за 1861,1862 и 1863 гг. Санкт-Петербург, 1865. 135 с.

7. Извлечение из отчета Женского благотворительного общества в Одессе за 1856 год. Журнал Министерства внутренних дел. СанктПетербург. 1857. Ч. 26. Кн. 9. Отд. 5. С. 2-7.

8. Императорское человеколюбивое общество: Сборник сведений по общественной благотворительности : в 7 т. Санкт-Петербург, 18751886.

9. Киевское благотворительное общество. Памятная книжка Киевской губернии. Издание киевского губернского статистического комитета. Киев, 1899. 460 с.

10. Линденмайер А. Добровольные благотворительные общества в эпоху великих реформ. Великие реформы в России 1856-1874 : сборник / ред. Л.Г. Захарова и др. Москва : Изд-во МГУ, 1992. C. 283-298.

11. Максимов Е.Д. Законодательные вопросы общественного попечения о бедных. Вестник благотворительности. СанктПетербург, 1897. № 12. С. 18-31.

12. Максимов Е.Д. Сословное призрение в России. Вестник благотворительности. Санкт-Петербург, 1898. № 4. С. 30-37.

13. Календарь Юго-Западного края на 1873 год / ред. В. Борисов, П. Чубинский. Киев : изд. В. Борисова и П. Чубинского, 1873. 517 с. 
14. Отчет взаимного вспомоществования общества акушерок г. Одессы за 1891. Одесса, 1892.93 с.

15. Отчет о деятельности общества попечительства о женском образовании в г. Екатеринославле за 1891-92 гг. Екатеринославль, 1893. $19 \mathrm{c}$.

16. Отчет о деятельности Харьковского общества распространения в народе грамотности за 1898 г. Харьков, 1899. 370 с.

17. Отчет правления Дамского общества вспомоществования бедным роженицам г. Одессы за время с 1883 по 1890 гг. Одесса, 1990. $93 \mathrm{c}$.

18. Пирогов Н.И. Военно-врачебное дело и частная помощь на театре войны в Болгарии и в тылу действующей армии в 1877-78 гг. Санкт-Петербург, 1879. 768 с.

\section{Information about author:}

Volkova I. O.

Candidate of Political Sciences, Associate Professor at the Department of Philosophy,

History and Political Science Odessa State Agrarian University 13, Panteleimonivska str, Odessa, Ukraine 